\section{Evaluation of Apically Extruded Debris Using Continuous Rotation, Reciprocation, or Adaptive Motion}

\author{
Ozgur Genc Sen¹, Burcu Bilgin², Sibel Koçak², Baran Can Sağlam², Mustafa \\ Murat Koçak²
}

\author{
'Department of Endodontics, \\ Faculty of Dentistry, Yuzuncu \\ Yil University, Van, Turkey \\ ${ }^{2}$ Department of Endodontics, \\ Faculty of Dentistry, Bulent Ecevit \\ University, Zonguldak, Turkey \\ Correspondence: Ozgur Genc \\ Sen, Zeve Campus, 65080, Van, \\ Turkey. Tel: +90-505-688-4429. \\ e-mail: dr.ogenc@yahoo.com
}

The aim of this study was to compare the amount of apically extruded debris during root canal instrumentation using ProTaper Next (PTN), Twisted File (TF) Adaptive, and Reciproc instruments. Forty-five extracted human maxillary canines were selected and randomly assigned into 3 groups. The root canals were prepared using PTN instruments with continuous rotation $(n=15)$, TF Adaptive instruments with adaptive motion $(n=15)$, Reciproc instruments with reciprocating motion $(n=15)$. During the preparations, canals were irrigated using distilled water and material extruded apically was collected in preweighed Eppendorf tubes. After a 5-day drying period in an incubator, the tubes were weighed and the dry weight of the extruded debris was calculated. Data distributions were assessed via the Shapiro-Wilk test, and groups were compared via the Kruskal-Wallis test. The greatest amount of debris extruded by TF Adaptive and the least by PTN, but the difference was insignificant between groups $(p=0.259)$. All instrumentation systems were associated with debris extrusion.
Key Words: apical extrusion, canal preparation, motion kinematics.

\section{Introduction}

Apical debris extrusion may be associated with pain and/or swelling in the presence of a severe inflammatory response in clinical practice (1). However, debris extrusion is an undesired result of mechanical instrumentation of the root canal, and none of the available instrumentation systems can completely prevent extrusion (2-6). Hence, techniques to minimize the phenomenon have been investigated (2). Apical debris extrusion reportedly varies based on kinematics, taper, cross-section, file number, and cutting efficacy (7).

A recent review (8) reported that inflammatory reaction due to debris extrusion is influenced by the type of movement and instrument design. However, there have been contradictory results on motion kinematics and debris extrusion. Some studies reported that reciprocating motion produced more debris than continuous rotating motion whereas some of them reported opposite results (7,9-13). Instrument systems operated with adaptive motion are relatively new and, research in this area is more limited (14-16).

The ProTaper Next (PTN) system (Dentsply Maillefer, Ballaigues, Switzerland) consists of three instruments made of an M-wire nickel titanium (NiTi) alloy. The M-wire alloy is manufactured via a thermal process. The variable taper design provides improved strength and flexibility (17). During the preparation, the files exhibit a snake-like movement due to their design (6).

The Reciproc single-file system (VDW, Munich,
Germany) features a specialized motor that performs alternating clockwise (CW) and counterclockwise (CCW) motions collectively known as reciprocating motion, and it is recommended for single use. The system is made of heat-treated NiTi (Memory Wire, Dentsply Tulsa Dental Specialties, Tulsa, OK, USA) that is resistant to fatigue (18) As well as the heat treatment, the reciprocating motion also improves the resistance of the NiTi instrument to cyclic fatigue (19).

The Twisted File Adaptive (TFAdaptive, Axis/SybronEndo, Orange, CA, USA) system uses a combination of rotational and reciprocating motions. The motion kinematic depends on the resistance of dentine during the preparation. Continuous rotation is used when there is minimal or no applied load. When the file engages dentine or a load is applied, the endodontic motor activates specifically designed CW and CCW angles that vary from $600-0^{\circ}$ up to $370-50^{\circ}$ reciprocation motion (20).

Yılmaz and Özyürek (16) recently compared the amounts of debris extruded apically using PTN, Reciproc and TF Adaptive systems in retreatment procedures. However, these 3 systems have not been compared in terms of debris extrusion during root canal instrumentation yet. The current study compared the performance of the ProTaper Next, Reciproc, and TF Adaptive instruments with regard to the apical extrusion of debris produced during root canal preparation. The null hypothesis was that the motion of instruments would have no effect on the amount of apical 
debris extruded.

\section{Material and Methods}

Forty-five extracted human maxillary canines of similar length were selected. The sample size was determined based on similar studies (21-23) in the literature. Calculus and soft-tissue remnants were removed mechanically from the external root surface, and digital radiographs were taken from mesiodistal and buccolingual directions to determine root canal morphology. Teeth with more than one root canal and apical foramen, immature root apices, or a root canal curvature of more than $10^{\circ}$ were excluded. The incisal surfaces of the teeth were flattened with a high-speed bur, so that root canals showed a standardized length of 22 $\mathrm{mm}$. Access cavities were prepared and the working length (WL) utilized was $1 \mathrm{~mm}$ short of the length of the initial instrument (size 10) that was visible at the major apical foramen. The teeth in which the apical minor constriction was gauged larger than \#20 K-file were excluded from the study.

Debris collection was achieved via a model described by Myers and Montgomery (24). An analytical balance (Radwag, Radom, Poland) was used to determine the initial $\vec{s}$ weight of the previously removed cover, with a degree \pm of accuracy of $10-5 \mathrm{~g}$. The average of three consecutive measurements was recorded as the initial weight. The $\therefore$ roots were inserted into a previously created hole on the cover. In order to equalize the air pressure, a 27-gauge needle was placed alongside the cover. Each cover was then attached to an Eppendorf tube, and the tubes were fitted into vials. A single operator, to avoid variation and eliminate bias, performed all the cleaning, shaping, and irrigation procedures. A total of $5 \mathrm{~mL}$ of distilled water was used to irrigate each root canal.

The 45 roots were randomly divided into three equal experimental groups $(n=15)$ based on the NiTi system that was to be used on them, as follows:

Group 1: PTN files were used in the sequence ProTaper Universal SX (19/.04), PTN X1 (17/.04), PTN X2 (25/.06), PTN X3 (30/.07), PTN X4 (40/.06), and PTN X5 (50/.06) at a rotation speed of $300 \mathrm{rpm}$ and $2 \mathrm{Ncm}$ torque with an endodontic motor (X-Smart, Dentsply, Maillefer). The SX file was used in the coronal thirds. The PTN files were used with a brushing outstroke motion. The motion was repeated until the $\mathrm{X} 5$ file reached the WL.

Group 2: TF Adaptive instruments were used in the sequence ML1 (25/.08), ML2 (35/.06), and ML3 (50/.04). The files were used with a gentle in-and-out motion and an Elements motor (SybronEndo, Glendora, CA) at full WL.

Group 3: A Reciproc R25 (25/.08) instrument was introduced into the canal, and when the instrument reached WL the procedure was repeated using a Reciproc
R50 (50/.05) with a reciprocating, slow, in-and-out pecking motion in accordance with the manufacturer's instructions.

The root canals were irrigated via a syringe that was placed $1 \mathrm{~mm}$ from the WL. After each instrument change, $2 \mathrm{ml}$ of distilled water was used for irrigation, and a total of $10 \mathrm{ml}$ of distilled water was used for each root. The teeth were removed from Eppendorf tubes, and the apical surfaces of the teeth were irrigated with distilled water to collect adhered debris. The dry weight of the extruded debris was obtained after a 5-day storage period in a $68^{\circ} \mathrm{C}$ incubator. A second researcher who was blinded to the group assignment weighed each tube via the same methodology used to ascertain the initial weight of the tube, in the same temperature and humidity conditions. The balance has been calibrated between the evaluations of each sample. The final weight of extruded debris was calculated by subtracting the weight of the empty tube from the weight of the tube containing the extruded debris.

Statistical analysis was performed with SPSS 19.0 software (SPSS Inc., Chicago, IL, USA). Data distributions were assessed via the Shapiro-Wilk test. Variables were expressed as mean \pm standard deviation, and groups were compared via the Kruskal-Wallis test. The significance level was set at $p<0.05$.

\section{Results}

Apical debris extrusion was evident in all groups, and there was no statistically significant difference in the amount of debris extrusion between the groups $(p=0.259)$. The TF Adaptive group exhibited the highest mean debris extrusion, and the PTN group exhibited the lowest. The means, standard deviations, medians, and ranges for all groups are shown in Table 1.

\section{Discussion}

Debris extruded from the apical foramen intraoperatively may result in postoperative pain (25). Thus, a reduction in debris extrusion during canal preparation is desirable in order to reduce postoperative pain following root canal treatment (26). The number of instruments used and the kinematics involved may contribute to debris extrusion during instrumentation (2). To the best of our knowledge, the amounts of apical debris extrusion associated with

Table 1. Means \pm standard deviation (SD), medians, and ranges (min, max) of the weight of apically extruded debris in each group (in grams).

\begin{tabular}{lccccc}
\hline Group & $\mathrm{n}$ & Mean $\pm \mathrm{SD}$ & Median & Min & Max \\
\hline 1 & 15 & $0.00046 \pm 0.00015$ & 0.0004 & 0.0003 & 0.0007 \\
2 & 15 & $0.00057 \pm 0.00020$ & 0.0005 & 0.0002 & 0.0009 \\
3 & 15 & $0.00052 \pm 0.00016$ & 0.0005 & 0.0003 & 0.0008 \\
\hline
\end{tabular}


the use of the ProTaper Next, Reciproc, and TF Adaptive systems have not yet been compared.

Standardization of the methodology used is essential for the minimization or elimination of procedural errors during the evaluation of apical debris extrusion. Single and straight roots have been used in numerous studies to evaluate amounts of debris extrusion during instrumentation $(5,26,27)$ Thus, in the present study canine teeth with single and straight roots were used in an effort to eliminate loss of WL and nonstandardized preparation and irrigation. The generally accepted methodology described by Myers and Montgomery (24) was used to collect apically extruded debris. A limitation of this methodology is the absence of a material that simulates the apical pressure of the periodontal ligament against the extrusion of debris. However, the methodology enables standardization for the purposes of comparing file systems. In order to eliminate potentially misleading results arising from the crystallization of sodium hypochlorite, distilled water was used as an irrigant. Additionally, as the size of the final instrument may affect the amount of apically extruded debris (26), all canals were prepared up to a tip diameter of 50 .

Most NiTi instrumentation systems work in a crowndown manner, while reciprocating systems simulate the balanced force technique (4) The instrumentation technique and the type of instrument used to prepare a root canal may affect the amount of debris extruded (28). Thus, the analysis of recently developed and widely used systems in this regard is warranted. The apical extrusion associated with PTN files has been evaluated in recent studies. Kocak et al. (26) compared the apical debris extrusion associated with the conventional ProTaper Universal system and the PTN system, and reported that the former extruded significantly more debris than the latter. As was the case in the current study, Capar et al. (5) reported that the PTN system was associated with less debris extrusion than the ProTaper Universal system. In that study, it was reported that there was no significant difference between the TF Adaptive and PTN systems, which is concordant with the results of the current study.

All the instrumentation systems tested in the current study have different cross-sections and kinematics. The Reciproc uses a reciprocating movement only, the PTN uses continuous rotation, and the TF Adaptive predominantly uses a rotary movement. In the TF Adaptive system, a reciprocating movement is only activated when resistance against the dentin walls occurs (15) Reciproc instruments have an S-shaped cross-section with two cutting blades (29), TF adaptive files have a triangular cross-section (15) and PTN instruments have an off-center rectangular cross section (6). Despite the instruments having different cross- sections and kinematics, they did not exhibit significantly different amounts of apical debris extrusion. Therefore, the null hypothesis was accepted. Similar to the results of the current study, Karataş et al. (20) reported that continuous rotation was associated with the extrusion of less debris than $150^{\circ} \mathrm{CW}$ to $30^{\circ} \mathrm{CCW}$ reciprocating and adaptive motions using TF Adaptive instruments, but that the difference was not statistically significant. However, in that study the difference in reciprocating motion kinematics did significantly affect the amount of debris extruded (20).

The amount of apically extruded debris may differ depending on whether adaptive movement is predominant at the beginning of the instrumentation or at the point of apical refinement (20). Adaptive motion includes both rotation and reciprocation, depending on the stress placed on the file. The root canal anatomy, curvature of the root canal, and particularly the experience of the operator all play crucial roles in the movement kinematics of this system.

In conclusion, all the systems investigated were associated with apical extrusion of debris, and their different motion kinematics did not significantly affect the amount of apical debris extrusion. Clinicians should be aware of preventing postoperative pain associated with the amount of apically extruded debris. In addition, new methods to minimize apical debris extrusion should be investigated. Further studies are required to clarify the relationship between the quantity of extruded debris and postoperative flare-ups.

\section{Resumo}

0 objetivo deste estudo foi comparar a quantidade de detritos apicalmente extruidos durante a instrumentação do canal radicular usando os instrumentos ProTaper Next (PTN), Twisted File (TF) Adaptative e Reciproc. Quarenta e cinco caninos superiores humanos extraidos foram selecionados e distribuídos aleatoriamente em 3 grupos. Os canais radiculares foram preparados utilizando instrumentos PTN com rotação contínua ( $n=$ 15), instrumentos TF Adaptative com movimento adaptativo $(n=15)$, instrumentos Reciproc com movimento oscilatório $(n=15)$. Durante os preparos, os canais foram irrigados com água destilada e o material extruído foi coletado apicalmente em tubos Eppendorf pré-pesados. Após um periodo de secagem de 5 dias numa incubadora, os tubos foram pesados e o peso seco dos resíduos extruídos foi calculado. A distribuição dos dados foi avaliada pelo teste de Shapiro-Wilk e os grupos foram comparados pelo teste de Kruskal-Wallis. A maior quantidade de detritos extruídos foi proporcionada pelo TF Adaptive e a menor pelo PTN, mas a diferença não foi estatisticamente significante entre os grupos $(p=0,259)$. Todos os sistemas de instrumentação promoveram extrusão de detritos apicalmente.

\section{References}

1. Siqueira JF Jr. Microbial causes of endodontic flare-ups. Int Endod J 2003;36:453-463.

2. Tanalp J, Güngör T. Apical extrusion of debris: a literature review of an inherent occurrence during root canal treatment. Int Endod J 2014;47:211-221.

3. Kuştarci A, Akpinar KE, Er K. Apical extrusion of intracanal debris and irrigant following use of various instrumentation techniques. Oral Surg Oral Med Oral Pathol Oral Radiol Endod 2008;105:257-262.

4. Kocak S, Kocak MM, Saglam BC, Türker SA, Sağsen B, Er Ö. Apical 
extrusion of debris using self-adjusting file, reciprocating single-file, and 2 rotary instrumentation systems. J Endod 2013;39:1278-1280.

5. Capar ID, Arslan H, Akcay M, Ertas H. An in vitro comparison of apically extruded debris and instrumentation times with ProTaper Universal, ProTaper Next, Twisted File Adaptive, and HyFlex instruments. J Endod 2014;40:1638-1641.

6. Koçak MM, Çiçek E, Koçak S, Sağlam BC, Furuncuoğlu F. Comparison of ProTaper Next and Hyflex instruments on apical debris extrusion. Int Endod J 2016;49:996-1000.

7. Tinoco JM, De-Deus G, Tinoco EM, Saavedra F, Fidel RAS, Sassone LM. Apical extrusion of bacteria when using reciprocating single-file and rotary multifile instrumentation systems. Int Endod J 2014;47:560-566.

8. Caviedes-Bucheli J, Castellanos F, Vasquez N, Ulate E, Munoz HR. The influence of two reciprocating single-file and two rotary-file systems on the apical extrusion of debris and its biological relationship with symptomatic apical periodontitis. A systematic review and metaanalysis. Int Endod J 2016;49:255-270.

9. Arslan $H$, Doğanay $E$, Alsancak $M$, Çapar $I D$, Karataş $E$, Gündüz HA. Comparison of apically extruded debris after root canal instrumentation using Reciproc instruments with various kinematics. Int Endod J 2016;49:307-310.

10. De-Deus G, Neves A, Silva EJ, Mendonça TA, Lourenço C, Calixto C, et al. Apically extruded dentin debris by reciprocating single-file and multi-file rotary system. Clin Oral Investig 2015;19: 357-361.

11. Topçuoğlu HS, Düzgün $S$, Akpek F, Topçuoğlu A, Aktı A. Influence of glide path on apical extrusion of debris during canal preparation using single-file systems in curved canals. Int Endod J 2016;49:599-603.

12. Bürklein $\mathrm{S}$, Benten $\mathrm{S}$, Schafer E. Quantitative evaluation of apically extruded debris with different single-file systems: Reciproc, F360 and OneShape versus Mtwo. Int Endod J 2014;47:405-409.

13. Nayak G, Singh I, Shetty S, Dahiya S. Evaluation of apical extrusion of debris and irrigant using two new reciprocating and one continuous rotation single file systems. J Dent 2014;11:302-309.

14. Dinçer AN, Güneşer MB, Arslan D. Apical extrusion of debris during root canal preparation using a novel nickel-titanium file system: WaveOne Gold. JCD 2017;20:322-325.

15. Kirchhoff AL, Fariniuk LF, Mello I. Apical extrusion of debris in flatoval root canals after using different instrumentation systems. J Endod 2015;41:237-241.

16. Yılmaz K, Özyürek T. Apically extruded debris after retreatment procedure with Reciproc, Protaper Next, and Twisted File Adaptive instruments. J Endod 2017;43:648-651.

17. De-Deus G, Belladonna FG, Souza EM, Silva EJ, Neves Ade A, Alves H, et al. Microcomputed tomographic assessment on the effect of ProTaper
Next and Twisted File Adaptive systems on dentinal cracks. J Endod 2015:41:1116-1119

18. Shen $Y$, Qian $W$, Abtin $H$, Gao $Y$, Haapasalo M. Fatigue testing of controlled memory wire nickel-titanium rotary instruments. J Endod 2011;37:997-1001.

19. Kiefner $\mathrm{P}, \mathrm{Ban} \mathrm{M}$, De-Deus $\mathrm{G}$. Is the reciprocating movement per se able to improve the cyclic fatigue resistance of instruments? Int Endod J 2014;47:430-436.

20. Karataş E, Arslan H, Kırıcı DÖ. Alsancak M, Çapar ID. Quantitative evaluation of apically extruded debris with Twisted File Adaptive instruments in straight root canals: reciprocation with different angles, adaptive motion and continuous rotation. Int Endod J 2016;49:382385.

21. Silva EJ, Carapia MF, Lopes RM, Belladonna FG, Senna PM, Souza EM, et al. Comparison of apically extruded debris after large apical preparations by full sequence rotary and single-file reciprocating systems. Int Endod J 2016;49: 700-705.

22. Küçükyılmaz E, Savas S, Saygılı G, Uysal B. Assessment of apically extruded debris and irrigant produced by different nickel-titanium instrument systems. Braz Oral Res 2015;29:1-6.

23. Üstün Y, Çanakçi BC, Dinçer AN, Er O, Düzgün S. Evaluation of apically extruded debris associated with several Ni-Ti systems. Int Endod J 2015; 48:701-704

24. Myers GL, Montgomery S. A comparison of weights of debris extruded apically by conventional filing and Canal Master techniques. J Endod 1991;17:275-279.

25. Siqueira JF Jr, Rôças IN, Favieri A, Machado AG, Gahyva SM, Oliveira $\mathrm{JC}$. Incidence of postoperative pain after intracanal procedures based on an antimicrobial strategy. J Endod 2002;28:457-460.

26. Koçak MM, Çiçek E, Koçak S, Sağlam BC, Yılmaz N. Apical extrusion of debris using ProTaper Universal and ProTaper Next rotary systems. Int Endod J 2015;48:283-286.

27. Bürklein S, Benten S, Schäfer E. Quantitative evaluation of apically extruded debris with different single-file systems: Reciproc, F360 and OneShape versus Mtwo. Int Endod J 2014;47:405-409.

28. Bürklein $S$, Schäfer E. Apically extruded debris with reciprocating single-file and full-sequence rotary instrumentation systems. J Endod 2012;38:850-852.

29. Plotino G, Grande NM, Sorci E, Malagnino VA, Somma F. A comparison of cyclic fatigue between used and new Mtwo Ni-Ti rotary instruments. Int Endod J 2006;39:716-723. 